May 2021

\title{
10 Years of Excellence: Celebrating the Journal, Authors, Editors, and Readers
}

Catherine Liebau-Nelsen

School of Information, San Jose State University, catherine.liebau@sjsu.edu

Follow this and additional works at: https://scholarworks.sjsu.edu/ischoolsrj

Part of the Scholarly Communication Commons, and the Scholarly Publishing Commons

\section{Acknowledgements}

Thank you to all 84 editors who have served on the Editorial Board of the Student Research Journal; our Faculty Advisor, Dr. Anthony Bernier; the 2020-2021 Managing Editor, Sarah Wilson; and my family, who encouraged me to pursue this position on the Journal and to finish my graduate career strong!

\section{Recommended Citation}

Liebau-Nelsen, C. (2021). 10 Years of Excellence: Celebrating the Journal, Authors, Editors, and Readers. School of Information Student Research Journal, 11(1). https://doi.org/10.31979/2575-2499.110101 Retrieved from https://scholarworks.sjsu.edu/ischoolsrj/vol11/iss1/1

This article is brought to you by the open access Journals at SJSU ScholarWorks. It has been accepted for inclusion in School of Information Student Research Journal by an authorized administrator of SJSU ScholarWorks. For more information, please contact scholarworks@sjsu.edu. 


\section{Years of Excellence: Celebrating the Journal, Authors, Editors, and Readers}

\section{Keywords}

student research journal, peer review, graduate journal, scholarly research, scholarly publication

\section{Acknowledgements}

Thank you to all 84 editors who have served on the Editorial Board of the Student Research Journal; our Faculty Advisor, Dr. Anthony Bernier; the 2020-2021 Managing Editor, Sarah Wilson; and my family, who encouraged me to pursue this position on the Journal and to finish my graduate career strong!

\section{About Author \\ Catherine Liebau-Nelsen will graduate in August of 2021 with her MLIS from San Jose State University's School of Information. After serving as the Editor-in-Chief of the Student Research Journal for the last year, she is excited to see what awaits after graduate school. Liebau-Nelsen is currently a library technician at a junior high school library in her hometown.}


In June of 2011, the inaugural issue of the School of Information's Student Research Journal was published by the first Editor-in-Chief, Suzanne Scott. In Scott's editorial, she writes that library and information science professionals "must actively promote their expertise through evidenced-based [sic] research, scholarship, and communication" in order to "drive discourse of and action resolution to the issues of discovery, access, and preservation of critical information and new knowledge" (Scott, 2011, p. 5). Dr. Anthony Bernier undertook the task of researching how best to found the project - a graduate student journal written, edited, and run by graduate students. After several months of planning, the Student Research Journal began. The first Editorial Team consisted of Scott as the Editor-in-Chief; Richard Thomchick as the Managing Editor; Cynthia M. Cohen, Samantha Godbey, James E. Hicks, Kimberly Price, and Theresa Putkey as Content Editors; and Susan E. Edwards and Colleen Vincent as Copy Editors. Eighty-four editors have been a part of the Editorial Team, and the SRJ will welcome five additional editors to its ranks this coming Fall. For the last decade, Dr. Bernier has served as the Faculty Advisor for the $S R J$ and keenly inspired and offered guidance to the editors with whom he has worked.

Even at the Journal's conception, the $S R J$ aimed to help authors reach escape velocity - the topic of Dr. Bernier's invited contribution in that first issue. It remains a piece that is read by each incoming $S R J$ editor to present the types of manuscripts that we look for and the sort of constructive critiques we offer. According to Bernier, escape velocity refers to the level of original or pertinent thought contained within a manuscript that allows it to build upon and contribute to current discourse rather than simply restating what has already been said. At the start of the Journal, the success of the SRJ was measured by pieces published; articles were the only submissions accepted at the time. Later, book reviews and evidence summaries were added to the mix. The first book review - Mary Vasudeva's review of Overcoming Information Poverty: Investigating the Role of Public Libraries in the Twenty-First Century by Anthony McKeown - was published in the Student Research Journal in 2017. An evidence summary wasn't published in the SRJ until 2019 when SRJ's own Content Editor, Channon Arabit, published "Digital Commons and CONTENTdm: Not Entirely Accessible." A decade of growth and redefining 'success' has led the Journal to measure its worth not by the number of publications but by the number of student submissions put through double-blind peer review and by the quality of content published. Coming back to the concept of escape velocity, our goal is to not only publish articles, book reviews, and evidence summaries that reach escape velocity but also to help authors' work "'break free' of the gravitational pull of current scholarship" (Bernier, 2011, p. 10) with the acute observations and critical notes from our editors.

Because I have only been present to witness the last year of the $S R J$ 's progress and continued success, I asked several previous editors to describe their experiences working on the Journal. Among the reflections, similarities stand out 
among each: The experience of working as an editor for the $S R J$ is referred to as "the best thing I did in library school" (Meyers, E., personal communication, October 16, 2021), "the highlight of my time at SJSU" (Hockin, T., personal communication, January 7, 2021), "hands down, my most rewarding experience while at SJSU" (Greggs, R., personal communication, January 30, 2021), "among the most valuable [experiences] of my graduate degree" (Pistorino, P., personal communication, January 29, 2021), and "the highlight of my tenure at the iSchool" (Price, M., personal communication, February 3, 2021).

The Journal has undoubtedly come a long way in the last ten years. Thank you to all of the authors, editors, readers, and faculty who have brought the $S R J$ to its current status at the SJSU iSchool and in scholarship, in general. I am beyond pleased and proud of what our current editorial team and all of our predecessors have accomplished.

\section{References}

Arabit, C. (2019). Digital Commons and CONTENTdm: Not entirely accessible. School of Information Student Research Journal, 9(1). https://doi.org/10.31979/2575-2499.090103

Bernier, A. (2011). Reaching escape velocity and the purpose of SLIS Student Research Journal. School of Information Student Research Journal, 1(1). https://doi.org/10.31979/2575-2499.010102

Scott, S. (2011). Collaborative scholarship in library and information science. School of Information Student Research Journal, 1(1). https://doi.org/10.31979/2575-2499.010101

Vasudeva, M. (2017). Book review: Overcoming information poverty: Investigating the role of public libraries in the twenty-first century, Anthony McKeown. School of Information Student Research Journal, 6(2). https://doi.org/10.31979/2575-2499.060205 